\title{
SOSIALISASI ETIKA PEMANFAATAN TEKNOLOGI MEDIA SOSIAL DALAM PENYAMPAIAN INFORMASI SESUAI UU ITE
}

\author{
Fitriana Destiawati, Aulia Paramita, Harry Dhika, Musa Jaya \\ Program Studi Informatika, Fakultas Teknik dan Ilmu Komputer, \\ Universitas Indraprasta PGRI, Indonesia \\ honeyzone86@gmail.com
}

\begin{abstract}
As internet and cellphone technology advances, social media also develops rapidly. In an open communication space such as social media, it is often not realized that there are rules that bind it. The cases charged with the ITE Law for violations are the cases of Prita Mulyasari and Yogi Santani. The ITE Law must continue to be socialized, so that people can understand the legal rules that guide social interactions in cyberspace. For this reason, this community service activity seeks to provide counseling so that beneficiaries can understand more about healthy communication via the internet. The purpose of this activity is to provide an understanding of the knowledge of the ITE Law so that it is more specific to social media which makes them aware of the rules of attitude and behavior in cyberspace.
\end{abstract}

Keywords: Socialization, Social Media, Technology, ITE Law

\begin{abstract}
Abstrak
Seiring kemajuan teknologi internet dan ponsel, media sosial juga berkembang pesat. Dalam ruang komunikasi terbuka seperti media sosial, seringkali tidak disadari ada aturan yang mengikatnya. Kasus-kasus yang dijerat UU ITE atas pelanggaran adalah kasus Prita Mulyasari dan Yogi Santani. UU ITE harus terus disosialisasikan, agar masyarakat dapat memahami aturan hukum yang menjadi pedoman interaksi sosial di dunia maya. Untuk itu, kegiatan pengabdian masyarakat ini berupaya memberikan penyuluhan agar penerima manfaat dapat lebih memahami tentang komunikasi sehat melalui internet. Metode yang dilakukan yakni pendampingan dan penyuluhan yang dilakukan. Tujuan dari kegiatan ini untuk memberikan pemahaman akan pengetahuan UU ITE sehingga lebih spesifiknya pada social media yang membuat tahu akan aturan bersikap dan berperilaku dalam dunia maya.
\end{abstract}

Kata Kunci: Sosialisasi, Media Sosial, Teknologi, UU ITE

Submitted: 2020-09-07

Revised: 2020-09-21

Accepted: $2020-09-22$

\section{Pendahuluan}

Teknologi komunikasi telah berkembang demikian pesatnya. Penyediaan akses informasi yang tak kenal batas dan waktu seperti layanan internet menjadi alat komunikasi yang penting saat ini, sehingga kita seolah-olah dimanjakan oleh perkembangan teknologi sistem informasi tersebut. Teknologi pula yang menjadikan pergeseran gaya hidup masyarakat Indonesia yang ketergantungan pada akses internet (Nasution, 2019). Saat teknologi internet dan mobile phone makin maju maka media sosial pun ikut tumbuh dengan pesat. Dengan adanya media sosial semua orang bisa memiliki medianya sendiri yang bisa membuat, menambahkan, mengedit, video, gambar, dan berbagai model konten lainnya. 
Tabel 1. Data Scimago Journal "Social media" AND "UU ITE"

\begin{tabular}{|c|c|c|c|c|c|c|c|}
\hline \multirow{2}{*}{ Year } & \multicolumn{6}{|c|}{ Scimago Journal Rank } & \multirow{2}{*}{$\begin{array}{l}\text { Sub } \\
\text { Total }\end{array}$} \\
\hline & Q1 & Q2 & Q3 & Q4 & NQ & NI & \\
\hline 2015 & 2 & 37 & 3 & 0 & 1 & 127 & 170 \\
\hline 2016 & 2 & 43 & 0 & 1 & 0 & 173 & 219 \\
\hline 2017 & 0 & 13 & 5 & 0 & 3 & 343 & 364 \\
\hline 2018 & 10 & 24 & 15 & 5 & 5 & 416 & 475 \\
\hline 2019 & 10 & 6 & 10 & 2 & 0 & 458 & 486 \\
\hline 2020 & 12 & 2 & 15 & 2 & 1 & 207 & 239 \\
\hline \multicolumn{7}{|c|}{ Total results } & 1953 \\
\hline
\end{tabular}

Interaksi sosial melalui media sosial dengan komunikasi dua arah, bisa menjadi bersifat privat maupun terbuka. Munculnya berbagai macam media sosial memberikan pengaruh langsung baik positif maupun negatif (Ardian, Sundani, \& Ningrum, 2019). Komunikasi yang bersifat terbuka, tidak disadari bahwa ada aturan yang mengikatnya. Secara garis besar, UU ITE telah cukup menjawab kebutuhan orang-orang dalam melakukan kegiatan di dunia cyber (Safarina, Mukmin, \& Sanusi, 2016). Secara umum sosialisasi adalah sebuah proses seumur hidup yang berkenaan dengan bagaimana individu atau instansi mempelajari suatu norma, dan nilai social yang terdapat dalam kelompoknya agar dapat berkembang (Ayu, 2019). UU ITE harus terus disosialisasikan, agar masyarakat dapat memahami aturan hukum yang menjadi pedoman interaksi sosial di dunia maya. Untuk itulah kegiatan pengabdian masyarakat ini berupaya untuk memberikan penyuluhan agar penerima manfaat menjadi lebih paham tentang berkomunikasi sehat melalui internet.

Pada tabel 1. Mengenai jurnal yang membahas mengenai Sosial media dan membahas UU ITE diperoleh banyak sekali sumber jurnal untuk kajian pengembangan mulai dari rentang Scopus Quartile 1 hingga Quartil 4, naskah Non Quartil dan naskah Non Indexing. Table 1. Memberikan informasi bahwa pokok bahasan ini sangat fenomenal dan sedang popular, dimana kajian dilakukan selama 5 tahun terakhir dan diperoleh data yang sangat istimewa yakni sebanyak 1953 penelitian, keyword pencarian yang digunakan yakni "Social media" AND "UU ITE" hal ini membuat kajian ini menjadi sangat penting, untuk dijadikan pembahasan dalam kegiatan pengabdian masyarakat.

\section{Metode}

Kegiatan dilaksanakan dengan cara observasi langsung terhadap mitra yang menjadi target kami. Pada saat melakukan observasi kami melihat langsung bagaimana kondisi dan situasi mitra. Wawancara dilakukan dengan beberapa guru yang menjadi target kami untuk menerima manfaat kegiatan kami. Dalam hasil wawancara yang berlangsung beberapa menit, kami mendapat kesimpulan bahwa guru di mitra kami sudah mengetahui ada banyak kasus yang melibatkan penggunaan media sosial namun mereka tidak mengetahui secara persis undang-undang yang mengatur tentang pencemaran nama baik melalui media sosial, sehingga mitra membutuhkan pengetahuan mendalam tentang etika dalam menggunakannya. Maka kami pun menawarkan solusi dengan menyediakan apa yang menjadi kebutuhan mitra. Dengan melakukan sosialisasi 
kepada guru tentang etika pemanfaatan teknologi media sosial dalam penyampaian informasi sesuai UU ITE.

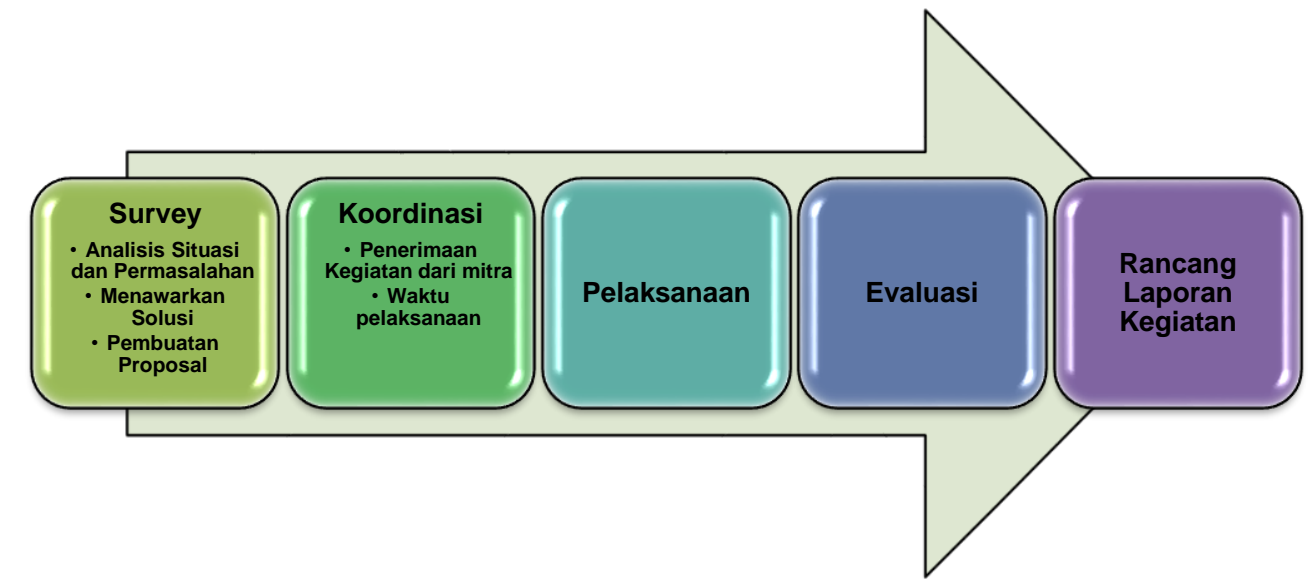

Gambar 1. Metode Pelaksanaan Kegiatan Abdimas

\section{Hasil dan Pembahasan}

Kami melakukan analisis situasi dalam mitra, sebelum dilaksanakannya kegiatan pengabdian masyarakat ini, supaya manfaat yang diterima sesuai dengan apa yang dibutuhkan oleh mitra. Penerima manfaat dalam pelaksanaannya adalah SD Lentera Insan yang terletak di kawasan Komp. Permata Puri I Blok F8 No. 1A Radar AURI, Cimanggis, Depok. Kasus yang sudah dijerat dengan UU ITE, yaitu Kasus Prita Mulyasari dan Yogi Santani. Prita Mulyasari didakwa dengan Pasal 27 Ayat (3) Undang-Undang ITE tentang pencemaran nama baik lewat dunia maya. Pada Kasus Yogi Sentani, penyidik Mabes Polri menuduh Yogi melanggar Pasal 35 jo Pasal 51 Ayat (1) UU ITE. Yogi diduga menyebarkan foto korban Sukhoi Superjet 100 di Cijeruk Gunung Salak, yang ternyata foto tersebut adalah korban tragedi pesawat di India pada tahun 2010.

Pengguna media sosial perlu berhati-hati dalam berkomunikasi, UU ITE harus terus disosialisasikan, agar masyarakat dapat memahami aturan hukum yang menjadi pedoman interaksi sosial di dunia maya. Pengguna media sosial sangat beragam dari usia anak-anak hingga orang dewasa. Diasumsikan, pengguna media sosial di kalangan remaja cukup signifikan jika dikaitkan dengan karakteristik kelompok usia remaja. Oleh sebab itu, potensi pelanggaran hukum pada kelompok usia remaja dalam pemanfaatan media sosial juga signifikan. Apalagi belum semua pengguna media sosial menggunakan secara baik. Media sosial digunakan tidak baik untuk sebagian orang atau kelompok tertentu untuk mencerca dan mencemarkan nama baik orang lain.

Pelaksanaan kegiatan pengabdian masyarakat ini dilakukan sesuai dengan jadwal yang disetujui oleh mitra sehingga tidak mengganggu kegiatan belajar dan mengajar. Kegiatan telah dilakukan beberapa tahap yaitu :

1. Tim pengabdian masyarakat melakukan survey ke mitra.

2. Tim pengabdian masyarakat melakukan koordinasi dengan mitra perihal perizinan dan teknik pelaksanaan jika mitra menyetujui kerja sama.

3. Sosialisasi etika pemanfaatan teknologi media sosial dalam penyampaian informasi sesuai UU ITE.

4. Evaluasi mitra dan tim pengabdian masyarakat terhadap respon siswa.

5. Menyusun Laporan Akhir kegiatan pengabdian masyarakat. 
Materi yang disampaikan pada saat pelaksanaan mencakupi:

1. Pengertian media sosial media beserta contoh aplikasinya.

2. Pengertian jejaring sosial beserta contoh aplikasinya.

3. Pertumbuhan media sosial.

4. Peran serta fungsi media sosial.

5. Manfaat jejaring sosial yang sebenarnya.

6. Pidana penjara dan denda terkait pasal pencemaran nama baik dalam UU ITE.

Tujuan dari pelaksanaan kegiatan ini adalah agar guru memiliki pengetahuan lebih luas mengenai Undang-undang yang mengatur tentang pencemaran nama baik melalui media sosial dan etika dalam menggunakan media social bagi orang tua wali murid ataupun guru itu sendiri dan diharapkan pengetahuan yang sudah diterima akan diajarkan kepada murid atau anak-anak yang sekarang cenderung sudah menggunakan media sosial. Hal ini sangat penting agar tidak terjadi lagi pelanggaran-pelanggaran yang disebabkan oleh penggunaan media sosial.

Berdasarkan analisis situasi yang dijelaskan sebelumnya maka kami melihat adanya permasalahan mitra yaitu dibutuhkannya pengetahuan lebih luas tentang etikaetika dalam menggunakan media social bagi orang tua wali murid ataupun guru dan diharapkan pengetahuan yang sudah diterima akan diajarkan kepada murid atau anakanak yang sekarang cenderung sudah menggunakan media sosial, agar tidak terjadi lagi pelanggaran-pelanggaran yang disebabkan oleh penggunaan media sosial. Dari uraian tersebut, dapat disimpulkan mengenai masalah yang dihadapi yaitu:

1. Kurangnya beretika yang baik dalam menggunakan media sosial

2. Belum memiliki pengetahuan mengenai undang-undang yang mengatur tentang pencemaran nama baik melalui media sosial.

Untuk memenuhi kebutuhan mitra dalam memberikan pengetahuan beretika di media sosial, maka kami menawarkan solusi.berupa :

1. Penyuluhan mengenai media social dan etika yang penting untuk diketahui dalam menggunakannya.

2. Sosialisasi tetang beberapa kasus di indonesia yang melakukan pelanggaran hukum teknologi informasi melalui media sosial.

3. Sosialisasi tentang kesadaran akan batas penyampaian informasi menggunakan teknologi media sosial sehingga tidak merugikan orang lain dan diri sendiri.

4. Penyuluhan mengenai bahaya dari pelanggaran etika berteknologi khususnya dalam penyampaian informasi menggunakan media sosial.

5. Sosialisasi undang - undang ITE.

Media sosial yang jika dimanfaatkan dengan baik akan memberikan manfaat yang positif, namun jika disalahgunakan akan berujung pada pidana, baik kurungan maupun denda (Susilowati \& Irpan, 2020). Masyarakat sebagai pengguna media sosial harus menjadi pengguna yang cerdas yang mematuhi etika dan aturan hukum yang berlaku (Triwanto \& Aryani, 2020). Undang undang yang mengatur tentang ITE dalam KUHP, khususnya Pasal 310 Ayat (1) masalah pencemaran nama baik. Sementara UndangUndang Hukum Pidana Pasal 310 Ayat (1) juncto Undang-Undang Nomor 11 Tahun 2008 tentang Informasi dan Transaksi Elektronik, UU ITE ini juga diatur berbagai ancaman hukuman bagi kejahatan melalui internet/dunia cyber. 


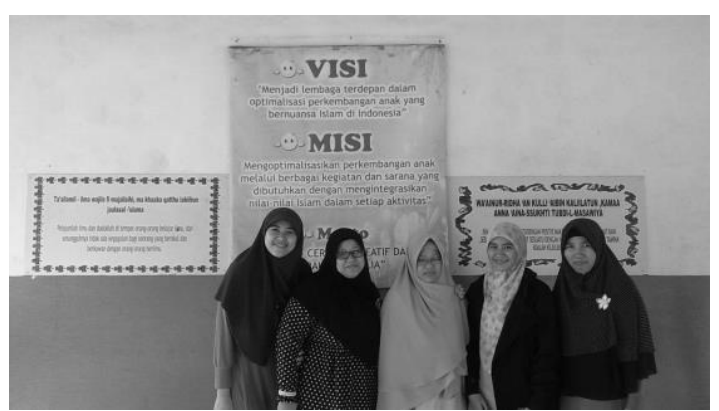

Gambar 2. Kegiatan Pendampingan

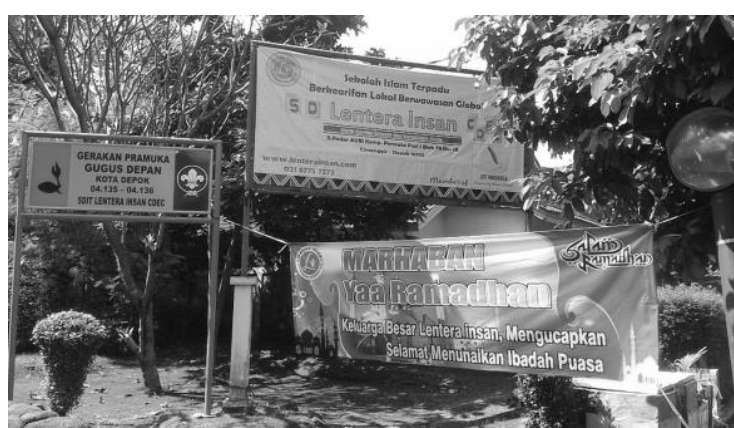

Gambar 3. Mitra Pengabdian

Target yang dicapai adalah sebagai berikut:

1. Meningkatkan kesadaran guru dan walimurid menggunakan teknologi khususnya media sosial dengan baik agar bisa di ajarkan dengan murid di SD Lentera Insan.

2. Peningkatan kompetensi guru - guru dalam memanfaatkan teknologi internet khususnya media sosial agar bisa dimanfaatkan dalam proses belajar mengajar.

3. Peningkatan pemahaman UU ITE dalam memanfaat media sosial.

Luaran dari kegiatan pengabdian ini pada mitra kami yaitu guru dan wali murid di SD Lentera Insan:

1. Jasa penyuluhan etika dalam menggunakan teknologi seperti media sosial

2. Jasa sosialisasi pelanggaran etika penggunaan media sosial dengan menyampaikam beberapa kasus media sosial yg menyerang nama baik seseorang.

3. Jasa sosislisasi mengenai batas penyampaian informasi menggunakan media sosial dengan baik sehingga tidak merugikan orang lain dan diri sendiri.

4. Jasa sosialisasi undang-undang ITE.

5. Kesadaran guru bahwa adanya etika berteknologi sehingga hal tersebut dapat dibagikan kepada para siswa yang merupakan juga pengguna media sosial.

Hasil dari sosialisasi dan evaluasi bersama mitra dalam kegiatan pengabdian masyarakat:

1. Wali murid dan guru mengetahui berbagai macam media sosial yang sedang tren dikalangan masyarakat khususny oleh siswa.

2. meningkatkan kerjasama dan interaksi sosial jejaring sosial dan pemanfaatannya baik sebagai pengajaran ataupun untuk membimbing siswa agar dapat meningkatkan proses belajar mengajar meskipun diluar kelas

3. melihat dan memantau bersama guru dan orang tua murid agar tidak terjadi kesalahan penggunaan media sosial untuk siswa

4. mengetahui undang undang undang-undang yang mengatur berbagai perlindungan hukum atas setiap kegiatan yang memanfaatkan sarana internet sebagai medianya khususnya untuk media social

\section{Kesimpulan}

Dalam menyelesaikan masalah yang dihadapi mitra yaitu kurangnya pengetahuan beretika yang baik dalam menggunakan media sosial dikarenakan belum memiliki pengetahuan mengenai Undang-undang yang mengatur tentang pencemaran nama baik melalui media sosial.Maka solusi yang tepat yaitu sosialisasi etika pemanfaataan teknologi media sosial dalam penyampaian informasi sesuai UU ITE.Kami sebagai tim pengabdian 
masyarakat memberikan sosialisasi dengan menjelaskan terlebih dahulu materi-materi yang berkaitan dan juga contoh kasus yang terjadi dalam penggunaan media sosial khususnya yang berkaitan dengan pencemaran nama baik. Sehingga tujuan dari pelaksanaan kegiatan ini terpenuhi yaitu guru memiliki pengetahuan lebih luas mengenai Undang-undang yang mengatur tentang pencemaran nama baik melalui media sosial dan etika dalam menggunakan media social bagi orang tua wali murid ataupun guru itu sendiri dan diharapkan pengetahuan yang sudah diterima akan diajarkan kepada murid atau anak-anak yang sekarang cenderung sudah menggunakan media sosial. Hal ini sangat penting agar tidak terjadi lagi pelanggaran-pelanggaran yang disebabkan oleh penggunaan media sosial. Melalui jasa peningkatan ilmu pengetahuan yang kami berikan dalam kegiatan pengabdian masyarakat ini maka mitra pun mulai memiliki pemahaman akanpentingnya beretika yang baik dan benar dalam menggunakan media sosial khususnya yang berkaitan dengan penyampaian informasi.

\section{Daftar Pustaka}

Ardian, Z., Sundani, S. A., \& Ningrum, E. S. (2019). Sosialisasi Penggunaan Media Sosial Secara Positif dengan Topik " Menjadi Remaja Cerdas Dalam Bermedia Sosial " Di SMK Negeri 2 Banda Aceh Socialization Of Positive Use Of Social Media With The Topic Of "Being Intelligent Youth In Social Media " In Vocational School 2 Banda Aceh. 1(2), 22-26.

Ayu, S. M. (2019). Sosialisasi Undang-Undang Republik Indonesia No . 19 Tahun 2016 dan Kode Etik dalam Penggunaan Media Sosial Bagi Guru. 1(1), 40-49.

Nasution, M. A. (M). (2019). Universitas Dharmawangsa. Warta Dharmawangsa, (59), 290572.

Safarina, Mukmin, Z., \& Sanusi. (2016). Persepsi Mahasiswa FKIP Universitas Syiah Kuala Terhadap Pelaksanaan UU No 11 Tahun 2008 Tentang Informasi dan Traksaksi Elektronik (ITE). Jurnal Ilmiah Mahasiswa Pendidikan Kewarganegaraan Unsyiah, 1(11), 166-175.

Susilowati, E. Y., \& Irpan, I. (2020). Melawan Hoax Melalui Sosialisasi Undang-Undang Informasi Dan Transaksi Elektronik. Adi Widya: Jurnal Pengabdian Masyarakat, 4(1a), 32. https://doi.org/10.33061/awpm.v4i1a.3876

Triwanto, T., \& Aryani, E. (2020). Sosialisasi Tentang Penggunaan Media Sosial Yang Cerdas Dan Beretika. Adi Widya: Jurnal Pengabdian Masyarakat, 4(1a), 141. https://doi.org/10.33061/awpm.v4i1a.3878 